\title{
Teaching materials for ESL distance learning
}

\author{
Iris Memić-Fišić \& Nina Bijedić \\ Faculty of Information Technology \\ "Džemal Bijedic" University of Mostar, \\ Bosnia and Herzegovina
}

\begin{abstract}
Distance education, as a form of education that enables and promotes development of autonomous life-long learning skill, necessary to keep up with rapid changes and development in today's society, is a concept definitely worth considering. Teaching a foreign language in a distance education system is very challenging, primarily in terms of overcoming the main gap lack of direct contact between teachers and learners. This paper focuses on the aspect of teaching materials used for ESL in a distance learning system.
\end{abstract}

Key words: distance learning; teaching materials; ICT (information and communication technology) in education.

\section{Introduction}

The dynamic development of technology has influenced all aspects of our lives. It has revolutionized the way we communicate, access and use information, as well as the way we learn. The amount of information and knowledge is rapidly increasing and that requires new education strategies which should enable the development of skills for life-long learning (Jarvis, 2010). As the life-long learning concept is gaining importance, the number of employed people in the student population, looking for flexible and effective opportunities for education, is also on the increase. This has resulted in the diversification of student population in terms of age, knowledge and previous experience, as well as the need for flexible approach in defining the curricula which should meet the constantly changing requirements of students (Knapper \& Cropley, 2000). Traditional educational systems cannot adequately meet the requirements of modern society and should be replaced by 
education models prioritizing development of skills needed in today's society (Yukiko, 2007).

In recent years, there has been a lot of discussion about the importance and value of electronic or distance education/learning. On the one hand, there are proponents of distance learning, claiming that the future of higher education is closely related to this concept. On the other hand, there are those reluctant to accept the changes brought by distance education. The interest in distance education is primarily invoked by the need to keep up with progress and development, and the realization that this form of education is efficient, considering the time and expenses of its implementation (Anderson, 2008; Bates, 2005; Boling et al, 2012). Common reasons preventing the acceptance of distance education on a larger scale are the lack of institutional and administrative support, students not being ready for this form of education, the lack of teachers' competences for use of technology, the need for technical support, time and efforts necessary to ensure that this education system is adequately and efficiently applied (Galusha, 1997; Garrison \& Anderson, 2003; Anderson, 2008; Maksumić, 2006).

New generations of students who grow up using new technology require the development of new teaching modalities. Advancements in technology and science, especially in the fields of artificial intelligence and psychology, as well as the improved understanding of learning strategies, enable the development of new techniques for adapting the process of learning to the needs and requirements of learners. The use of technology leads to increased flexibility in content and the organization of learning. The efficient integration of information and communication technology in the education system is a complex process involving not only the use of technology, but also other factors, such as adequate methodology and pedagogy, readiness to use new technology, competence of teachers etc.

The concept of distance learning has been analysed from different perspectives, like readiness of teachers and students to accept this form of education, the evaluation of software platforms to be used for distance learning, the interaction between teachers and students, drop-out rate in distance learning system etc. There has been a tendency to claim that the focus of such education system is on technology, but educators who have certain experience in distance education claim that technology is not the most important element and that other factors, such as the motivation of students and other pedagogical aspects, understanding the distance education system, and requirements that this system imposes on those participating in it, etc., must be considered (Garrison \& Anderson, 2003; Bates, 2005; Anderson, 2008).

Although a general assumption is that distance education is mostly present in the field of information technology, studies (Keegan, 2000; Garrison 
\& Anderson, 2003; White, 2003; Kearsley, 2005; Holmes \& Gardner, 2006) show that this system can be efficiently applied to various education fields. In research related to distance education, analyses and considerations regarding the foreign language teaching and learning are marginal. The main reason for that is not only the complexity of integrating all language skills in a virtual environment, but teachers' widespread scepticism about whether students can develop linguistic competences in the distance education system. Such doubts are mainly related to the lack of direct, face-to-face contact between teachers and students, and the idea that technology can be successfully used in the teaching material design and delivery, but that it cannot influence the results students need to achieve (Maksumić, 2006). However, the increasingly intensive integration of information and communication technology in education has had a major impact on the approaches to learning and teaching foreign languages, as well as the teachers' motivation to define new models and strategies for teaching. The number of higher education institutions choosing the approach of distance teaching of foreign languages and the use of computers for interaction, cooperation and access to information has been on the rise (Liegle \& Janicki, 2006; Boling et al, 2012). Modern technology has brought changes in the form and design of teaching materials, as well as the way students access and use these materials.

In order to ensure that the advantages of information and communication technology are most efficiently used in the process of learning foreign languages, teachers must be aware that their role has changed in comparison to the traditional system. They now lead students through the process of learning by planning, organizing, interacting with students, providing support in the learning process and defining teaching strategies to ensure the optimal use of advantages of distance education (Pennarola, 2007; White, 2007). Teachers in distance education are facing the challenge of evaluating and defining which teaching materials are adequate for this system, making necessary modifications in the materials, and structuring the teacher-tostudent and student-to-student interaction. Distance education provides ways to overcome some of the limitations typical for in-class environment, such as a large number of students, different levels of language proficiency, lack of time for direct contact and providing personalized information to all students, etc. The distance education system can be used by a high number of students at the same time. This system enables various types of flexibility in the learning process. Students work at their own pace and can have access to multimodal documents (text, visual elements, video, audio etc.) (Oxford et al, 1998; Curtis et al, 1999). Finally, distance learning system enables personalized approach to learning, as well as activities for different learning styles and levels of language proficiency, by offering teaching materials in different forms. Students individually decide about the sequence of learning, 
choose materials, tasks and activities, as well as type and degree of support (Cummins, 2002).

The integration of information and communication technology in the process of learning foreign languages is not related to only one specific learning theory. Each theory offers a different insight into a complex process of learning a foreign language. According to most theories about a foreign language acquisition, the main elements required in the process of acquiring a foreign language are understandable input information adequate for a specific level of knowledge (Krashen, 1987), two-way communication i.e. interaction (Long, 1985; Pica, 1994; Lightbown \& Spada, 1999), and opportunities for production of output information (Swain, 1995). Output information refers to language production, testing of rules and developing of communication skill. In order to be able to produce output information, students must have opportunities to interact in a language being acquired, so that they could come to conclusions about meaning, get feedback information, and recognize a need to make modifications in a language, with a goal of achieving successful communication (Long, 1996). Considering the aforementioned assumptions, two most important aspects in distance education are teaching materials and interaction among participants in this system.

This paper focuses on the element of teaching materials and what should be considered in the process of developing teaching materials for ESL distance learning.

\section{Literature review}

Teaching materials are an essential element in the teaching process (Herring \& Smaldino, 2001; Smaldino et al, 2015). The starting point in the process of designing electronic teaching materials and environment for distance learning should be pedagogical principles that define the choice of technological options (Chapelle, 1998; Doughty \& Long, 2003). Distance education should not limit teachers in the process of choosing teaching strategies, but, on the contrary, should open new options for enhancing the process of education (Westbrook, 2006; Smaldino et al, 2015).

Common approach in distance education systems with regard to teaching materials assumes that teaching materials are made or selected by teachers and delivered to students. Marland \& Store (1993) claim that in the early stages of distance learning systems, specific learning goals were defined, teaching content was selected and presented by teachers, interactive processes were mainly initiated, lead, and controlled by teachers who also provided feedback information. Such structured, clearly defined systems are 
favoured by students who like frontal teaching and who lack confidence in independent learning. The negative aspect of such systems is that students' learning is somehow limited since students do not develop a skill to select materials in accordance with their previous experience, needs and preferences in the learning process.

Nevertheless, the development and use of materials can be approached from a different perspective. Teaching materials can consist of various sources of information and students can select materials that suit their needs, preferences, abilities and progress. In this case, students decide on how the offered materials will be interpreted and used, which means that they create their own path of learning. A challenging point here is that students differ in their abilities to identify and evaluate how useful certain information is, as well as how the process of acquiring knowledge and achieving goals should be improved. However, students' needs, learning style, and the level of previous knowledge can be defined using appropriate questionnaires or other methods, and teaching materials can be accordingly selected, planned and structured.

The development of effective electronic teaching materials requires a combination of learning theories, making sure that chosen methods have positive effect on students' motivation and take into consideration individual differences, encourage interaction, give relevant feedback, enable learning in context and provide support during the process of learning. Teaching materials used in distance education must encourage and support autonomous learning, and, at the same time, provide support in different phases of learning (Moore \& Kearsley, 1996). Students differ in their abilities to perform autonomous learning, which depends on their personality, level of motivation and previous experience in the process of learning (Coldeway \& Spencer, 1982; Candy, 1991). Therefore, electronic teaching materials should include activities for different learning styles so that students could choose activities suitable for their learning style. Ally \& Fahy (2002) state that students with different learning styles have different preferences for support. Materials can be structured in different thematic modules in order to achieve not only variety but also flexibility, enabling different learning directions. Integrated in a distance learning system, such modules, with appropriate tools for navigation and resources, should enable students to define and monitor their learning process and path. Bonk \& Reynolds (1997) claim that teaching materials in a distance learning system should include activities through which students will relate new and old information, acquire new knowledge and develop metacognitive skills. Numerous studies have shown that it is necessary to encourage students to use their metacognitive skills in the learning process (Mayer, 1998; Sternberg, 1998; Yorke \& Knight, 2004). Self-evaluation questions and tasks with feedback information enable stu- 
dents to be aware of their progress and to use their metacognitive abilities to adjust their learning approach if necessary.

Furthermore, teaching materials used in distance education must provide clear and specific instructions and guidelines for work. Moore \& Kearsley (1996) point out the importance of this aspect because "guidelines for work replace usual discussion taking place between teachers and students in an in-class environment". It is very challenging to plan and develop teaching materials that will have sufficient guidelines and feedback information and that students can use independently. Certain elements that are common and "natural" in in-class teaching process must be very carefully considered in the process of designing electronic teaching materials. In this context, Garing (2002) points out the following elements:

- a great deal of teaching content is very often "in teacher's head" and not on a paper

- the role of a teacher as a motivator can often be neglected in the process of adapting teaching materials for use in a distance education system

- possibility to give feedback information as replies to potential problems and questions of students.

The Internet offers great amount of various content that can be used for teaching and learning a foreign language, but that requires a careful selection and possible modifications in order to enable adequate and effective use of such content in a distance education system. However, teachers of foreign language in a distance education system, especially those who teach a language for a specific profession, often choose to develop their own materials in order to meet specific needs and requirements of learners. With regard to developing electronic materials for teaching a foreign language in a distance education system, the following elements should primarily be considered: specific features of a distance education system, principles of teaching and learning of a foreign language, content relevance, learners' needs, and their learning styles. These elements define the combination of approaches to be applied in the process of developing teaching materials. Chosen strategies should enable cognitive processing of information, encourage meaningful learning and interaction, and motivate students. The materials need to be organized and presented so that they can be adapted to different needs and requirements, as well as to levels of language proficiency. Electronic materials for teaching a foreign language in a distance education system can be structured by skills, with sections for reading, writing, listening and speaking.

With regard to development of a reading skill, electronic teaching materials enable students to focus on different parts of text, mark different elements and use additional, related assignments and materials. Texts can be 
combined with graphical, audio and video materials, which help students activate previously acquired knowledge and apply strategy of assuming. What can be useful, especially for beginner-level students, is to combine simultaneous listening and reading, and use digital tools for repeated listening, marking parts of text, or translation.

When it comes to a skill of writing, one of the advantages of online environment is the possibility of saving and sharing written texts in different stages of writing, which has a positive impact on students' motivation. Distance education offers more options for the completion of listening tasks compared to in-class environment. Listening tasks in a distance education system can include not only audio and video content, but also different hyper-textual elements (e.g. transcripts or additional information that can be shown on screen during listening), electronic dictionaries that can be easily accessed, etc. In comparison to in-class environment, in distance education students are much more actively engaged in listening tasks. One of the significant advantages of distance education for the development of a listening skill is that resources and content can be accessed as many times as students consider it necessary.

The main advantage of a distance education system with regard to the development of a speaking skill is the possibility to make a recording that can be listened to, analysed and re-recorded, until a satisfactory level is achieved. In this way, students can reorganize information and find suitable and correct language forms and elements. Other advantages of distance education in terms of developing a speaking skill are: the availability of resources for development of comprehension and speaking production, time for processing, and the opportunity for all students to participate in conversation tasks that is not the case in the in-class environment where more advanced and confident individuals are dominant in this context.

\section{The study}

\subsection{Context}

Faculty of Information Technology (FIT) of Džemal Bijedić University in Mostar, is the first institution to introduce the concept of distance education in Bosnia and Herzegovina. FIT offers Bachelor and Master degree programs in the field of information technologies. The Bachelor degree program is offered through two options - in-class and through distance learning system. The curriculum for the Bachelor degree program includes the English language course in the first (English language I) and second year (English language II and III) of studies. 
The content of the English language courses is based on the CLIL (Content and Language Integrated Learning) method and involves activities related to various aspects of theory and application of information and communication technologies. The aim of this approach is to enable improvement of English language proficiency, as well as acquiring of knowledge in the field of information and communication technology.

There is a software platform for distance learning system that is used for distribution of the teaching materials. Teaching materials for the English language courses are distributed on a weekly basis. There are also regular online classes that are organized once a week. Continuous efforts are made to equalize effects of in-class and online teaching.

Teaching materials for the English language courses follow the same model, since this is considered to help students develop a feeling of a familiar learning framework. A unit consists of the following elements: text for reading, grammar section, listening part, and tasks (written and spoken). Students can also take part in activities organized on the forum and related to content of the lessons. This aspect is very important because it encourages students to socialize and to interact in a written and spoken form, creating a feeling of belonging to the community and increasing students' motivation. In order to ensure students' participation in forum discussions, these activities can be graded.

Online classes include listening, reading, speaking and writing activities, as well as grammar and vocabulary practice. Online classes enable interaction between teachers and students and among students. This gives students opportunities to ask questions, get necessary clarifications, ask for additional explanations and make suggestions. Participation in online classes has a positive impact on students' motivation and reduces a feeling of isolation.

\subsection{Methodology}

In the 2015/2016 academic year, a study involving in-class and distance learning students of first, second and third year of studies was carried out. It aimed to examine students' approaches to teaching and learning of English as a second language in the distance education system. The following methods were applied: collecting and primary processing of data, data sorting, contingency tables, visualization, Cronbach Alpha and Chi-squared test. The instrument used for data collection was a questionnaire. Data was entered with control using MS Excel, according the standard statistical methodology of assigning two persons for data input. Preliminary data analysis was performed using MS Excel, and it consisted of calculating descriptive statistics for each variable, and the verification of questionnaire by calculating Cronbach Alpha in order to prove that answers to questions are neither too 
diverse nor too similar. For the Cronbach Alpha calculation modalities of answers expressed on Likert scale were inverted where necessary. Data visualization, calculating frequencies relating answer modalities for pairs of questions, and hypothesis' testing were also performed in MS Excel. Hypothesis testing deployed Chi-squared test for contingency tables as the most appropriate method considering limitations of the method and used grouping of answers where necessary (due to small frequencies).

Data acquisition tool was a questionnaire developed by authors in order to obtain data to answer research questions. The methodology of questionnaire development followed the usual practice, involving at least one expert in the area of distance learning who proposed the list of questions of interest, one expert in questionnaire development methodology, and one statistician who insured that data were adequate for statistical analysis. The questionnaire consisted of four parts aside from basic student data, namely, teaching materials, language knowledge and skills improvement, communication and interaction, and motivation. All of the questions were in the form of proposed ordinal-polytomous statements, where the respondent had five options to choose from, in order to express agreement with them. Options were scaled according the Likert scale, with five options varying from "I agree" to "I totally disagree", or in one question from "Highly" to "Not at all".

A total of 624 students participated in the study, of which 378 were distance learning students and 243 were in-class students (three students did not indicate their studying status).

To the question about the number of years of previous English language learning, answers varied from 0 to 19 , median was 9 , mean was 8,84 , standard deviation was 2,90 and the coefficient of variation was 0,328 .

In order to explore if the perception of teaching materials quality depends on the studying status, authors deployed Chi-squared and Fisher exact tests (depending on the cell frequency value criterion), and tested statistical hypotheses. The same method was used to explore relationship between motivation and answers about teaching materials quality.

\subsection{Results and discussion}

In this paper, only the part of the study related to the teaching materials is presented.

The following three research questions directly referred to the teaching materials:

Q1: The content of the English language courses is interesting and adequately adapted to the requirements of IT students. 
Q2: Teaching materials for the English language courses are appropriately designed.

Q3: Teaching materials for English language courses are well-structured and simple to follow.

Cronbach Alpha was calculated for these three questions and its value was 0,784 . This value is within limits for testing a homogeneous set.

The following table shows frequency distribution for answers to the questions.

Table 1. Frequency distribution for answers to the questions about teaching materials for English language courses.

\begin{tabular}{|l|c|c|c|}
\hline ANSWER MODALITIES & Q1 & Q2 & Q3 \\
\hline I AGREE & $70 \%$ & $67 \%$ & $71 \%$ \\
\hline I PARTLY AGREE & $22 \%$ & $23 \%$ & $22 \%$ \\
\hline NO OPINION & $5 \%$ & $6 \%$ & $4 \%$ \\
\hline I PARTLY DISAGREE & $2 \%$ & $1 \%$ & $1 \%$ \\
\hline I DISAGREE & $1 \%$ & $3 \%$ & $2 \%$ \\
\hline
\end{tabular}

Data in Table 1 show that the majority of students have a positive opinion about the content, design and structure of the teaching materials for the English language courses. Out of 624 study participants, 70\% think that the content of the English language courses is interesting and adapted to requirements of IT students; $67 \%$ think that the teaching materials for the English language courses are appropriately designed, and 71\% think that the teaching materials for the English language courses are well-structured and easy to follow.

The statistical hypothesis testing (Fisher exact test) proved that for questions Q1 and Q2, answers were statistically independent from the studying status with $\mathrm{p}$-values $\mathrm{p}<0.01$ and $\mathrm{p}<0.05$, respectively. On the other hand, answers to question Q3 were not statistically independent with regard to the studying status, and the frequency distributions are presented in Table 2. Nevertheless, even if there exists some dependence, it is not statistically significant ( $\mathrm{p}$-value is $\mathrm{p}=0.1631$ ).

Table 2. Frequency distribution for answers to the question about teaching materials structure and ease of following for distance learning (DL) and inclass (IC) students.

\begin{tabular}{|l|c|c|}
\hline Q3 ANSWER MODALITIES & DL & IC \\
\hline I AGREE & $72 \%$ & $69 \%$ \\
\hline I PARTLY AGREE & $20 \%$ & $26 \%$ \\
\hline NO OPINION & $5 \%$ & $3 \%$ \\
\hline I PARTLY DISAGREE & $1 \%$ & $0 \%$ \\
\hline I DISAGREE & $2 \%$ & $1 \%$ \\
\hline
\end{tabular}


When it comes to the question about whether the additional resources (besides the teaching materials available in the distance learning system) were necessary to prepare for the English language final exams, 89\% of students said they did not need additional resources and $18 \%$ said they needed additional resources. We can conclude that the majority of students think that the teaching materials distributed in the distance learning system were sufficient for the English language final exams.

The statistical hypothesis testing (Chi-squared test) proved that answers to the question about teaching materials sufficiency were not statistically independent with regard to the studying status, and the frequency distributions are presented in Table 3. Again, the dependence is not statistically significant ( $\mathrm{p}$-value is $\mathrm{p}=0.2258$ ).

Table 3. Frequency distribution for answers to the question about teaching materials sufficiency for distance learning (DL) and in-class (IC) students.

\begin{tabular}{|l|c|c|}
\hline ANSWER MODALITIES & DL & IC \\
\hline YES & $19 \%$ & $16 \%$ \\
\hline NO & $81 \%$ & $84 \%$ \\
\hline
\end{tabular}

One of the questions in the study was related to the interest and motivation of students for the English language learning. The following table shows frequency distribution for answers to this question.

Table 4. Frequency distribution for answers to the question about motivation for learning of English language for all students, and for DL and IC students.

\begin{tabular}{|l|c|c|c|}
\hline ANSWER MODALITIES & Total & DL & IC \\
\hline NOT MOTIVATED & $5 \%$ & $6 \%$ & $4 \%$ \\
\hline POORLY MOTIVATED & $10 \%$ & $11 \%$ & $10 \%$ \\
\hline MODERATELY MOTIVATED & $44 \%$ & $46 \%$ & $41 \%$ \\
\hline VERY MOTIVATED & $26 \%$ & $23 \%$ & $33 \%$ \\
\hline HIGHLY MOTIVATED & $14 \%$ & $15 \%$ & $12 \%$ \\
\hline
\end{tabular}

Data in Table 4 show that majority of students were sufficiently motivated to learn the English language, which is an important factor in considering the way how they perceive the teaching materials. Testing hypothesis about independence of motivation and students' satisfaction explored in questions Q1, Q2, and Q3 (Chi-squared test) show that the answer modalities are statistically significantly independent ( $p$ values in all three cases are <0.001). Nevertheless, motivation might not be the same for DL and IC students, since $p$-value from Chi-squared test is $p=0.2923$. For that reason, frequency distributions of answers with regard to the studying status are presented in Table 4. 


\section{Conclusion}

The aim of this paper was to consider the elements of teaching materials for ESL in the distance education and to give certain guidelines to future practitioners of distance learning to help them maximize effects of this form of education.

The part of the study presented was mainly used as the tool for evaluation of the teaching materials developed for the English language courses at the Faculty of Information Technology. The evaluation of the teaching materials is a very important element in the process of planning and designing teaching materials, especially in distance education (Smaldino et al, 2015; Dick et al, 2011). Having feedback information from students, teachers can evaluate effectiveness of applied methods and make necessary modifications.

The results of the study showed that the majority of students had positive opinion about the content, design and structure of the teaching materials for the English language courses. It is important to point out that the difference in answers to the questions about the quality of teaching materials depending on the status of studying was not statistically significant. This means that both distance learning and in-class students evaluated teaching materials in a similar manner.

Both categories of students also answered in a similar manner to the question about the sufficiency of the teaching materials. A great majority stated that they did not need any additional resources apart from the teaching materials to prepare for the exam.

With regard to the element of motivation, there is a certain difference between distance learning and in-class students, showing that in-class students are more motivated for English language learning. Nevertheless, this difference is not statistically significant.

The further development of teaching materials requires keeping track of research, trends and innovation in the field of ICT and adapting content of the courses accordingly. With regard to the structure of the teaching materials, efforts need to be made to optimally integrate and use advantages of distance education and ICT in the process of teaching ESL.

\section{References:}

Anderson, Terry (2008). Theory and Practice of Online Learning. Canada: Athabasca University Press. 
Ally, Mohamed, Patrick Fahy (2002). Using students' learning styles to provide support in distance education. Proceedings of the Eighteenth Annual Conference on Distance Teaching and Learning. Madison.

Bates, Tony (2005). Technology, E-learning and Distance Education. London: Routlege.

Boling, Erica, Mary Hough, Hindi Krinsky, Hafiz Saleem, Maggie Stevens (2012). Cutting the distance in distance education: Perspectives on what promotes online learning experiences. Internet and Higher Education 15: 118-126.

Bonk, Curtis J., Thomas Reynolds (1997). Learner-centered Web instruction for higher-order thinking, teamwork and apprenticeship. Khan, Badrul, eds. WebBased Instruction. Englewood Cliffs, NJ: Educational Technology Publications: 167-178.

Candy, Phillip (1991). Self-Direction for Lifelong Learning. San Francisco, CA: JosseyBass Publishers.

Chapelle, Carol (1998). Multimedia CALL: Lessons to be learned from research on instructed SLA. Language Learning \& Technology 2(1): 21-39.

Coldeway, Dan, Robert Spencer (1982). Keller's personalised system of instruction: The search for a basic distance learning paradigm. Distance Education 3(1): 5171.

Cummins, James (2002). The potential of ICT to promote academic language learning. Proceedings of the 3rd International Conference Information and Communication Technology in Education. Rhodes: University of Aegean.

Curtis, Susan, Joanne Duchastel, Nebojša Radić, (1999). Proposal for an online language course. ReCALL, 11(2): 38-45.

Dick, Walter, Lou Carey, James Carey (2011). The Systematic Design of Instruction (7th edn.). NJ: Pearson Merrill.

Doughty, Catherine, Michael Long (2003). Handbook of Second Language Acquisition. New York: Basil Blackwell.

Galusha, Jill (1997). Barriers to learning in distance education. Interpersonal Computing and Technology 5(3): 6-14.

Garing, Phil (2002). Adapting and developing e-learning courses. The Challenge of Keeping the Quality. Conference Proceedings DEANZ, Evolving E-learning. Wellington, New Zealand, 77-85.

Garrison, D. Randy, Terry Anderson (2003). E-learning in the 21st Century: Framework for Research and Practice. London: Routledge.

Herring, Mary, Sharon Smaldino (2001). Planning for Interactive Distance Education: A Handbook (2nd edn.). Bloomington, IN: AECT Publications.

Holmes, Bryn, John Gardner (2006). Elearning, Concepts and Practice. London: Sage Publications Ltd.

Jarvis, Peter (2010). Adult Education and Lifelong Learning: Theory and Practice (4th edn.). London: Routlege.

Kearsley, Greg (2005). Online learning: personal reflections on the transformation of education, Educational Technology Publications 53(2): 113-116.

Keegan, Desmond (2000). Foundations of Distance Education. London: Routledge.

Knapper, Christopher, Arthur Cropley (2000). Lifelong Learning in Higher Education. London: Kogan Page.

Krashen, Stephen (1987). Principles and Practice in Second Language Acquisition. Englewood Cliffs, NJ: Prentice-Hall. 
Liegle, Jens, Thomas Janicki (2006). The effect of learning styles on the navigation needs of web-based learners. Computers in Human Behavior 22(5): 885-898.

Lightbown Pats, Nina Spada (1993, 1999). How Languages are Learned (1st and 2nd edn.). Oxford: Oxford University Press.

Long, Michael (1985). Input and second language acquisition theory. Gass, Susan, Carolyn Madden, eds. Input in Second Language Acquisition. Rowley, MA: Newbury House, 377-393.

Long, Michael (1996). The role of the linguistic environment in second language acquisition. William C. Ritchie, Tej K. Bhatia, eds. Handbook of Second Language Acquisition (2nd edn.). New York: Academic Press, 413-468.

Maksumić, Ismet (2006). Sistem učenja na daljinu, Unpubished Master's Thesis, Univerzitet “Džemal Bijedić", Fakultet informacijskih tehnologija, Mostar.

Marland, Percy, Ronald Store (1993). Some instructional strategies for improved learning from distance teaching materials. Keith Harry, John Magnus, Keegan Desmond, eds. Distance Education: New Perspectives. London - New York: Routledge, 137-157.

Mayer, Richard (1998). Cognitive, metacognitive, and motivational aspects of problem solving. Instructional Science 26(1): 49-63.

Moore, Michael, Greg Kearsley (1996). Distance Education: A Systems View of Online Learning. New York: Wadsworth.

Oxford, Rebeca, Yolanda Rivera-Castillo, Carine Feyten, Joyce Nutta (1998). Computers and more: Creative uses of technology for learning a second or foreign language. Paper presented at the conference Educational Technology in Language Learning, Theoretical Considerations and Practical Applications, Lyon, France.

Pennarola, Cristina (2007). English language learning on the (hyper)way. Teaching English with Technology, Journal for Teachers of English 7.1.

Pica, Teresa (1994). Research on negotiation: What does it reveal about second language learning conditions, processes, and outcomes? Language Learning 44(3): 493-527.

Rovai, Alfred (2002). Building a sense of community at a distance. International Review of Research in Open and Distance Learning 3(1): 1-16.

Smaldino, E. Sharon, Deborah L. Lowther, Cliff Mims, James D. Russell (2015). Instructional Technology and Media for Learning. New Jersey: Pearson Prentice Hall.

Sternberg, Robert (1998). Metacognition, abilities, and developing expertise: What makes an expert student? Instructional Science 26(1): 127-140.

Swain, Merrill (1995). Three functions of output in second language learning. Cook Guy, Barbara Seidlhofer, eds. Principles and Practice in the Study of Language. Oxford: Oxford University Press, 125-144.

Westbrook, Vivienne (2006). The virtual learning future. Teaching in Higher Education 11(4): 471-482.

White, Cynthia (2003). Language Learning in Distance Education. Cambridge: Cambridge University Press.

White, Cynthia (2007). Innovation and identity in distance language learning and teaching. Innovation in Language Learning and Teaching 1.1: 97-110.

Yorke, Mantz, Peter Knight (2004). Self-theories: some implications for teaching and learning in higher education. Studies in Higher Education 29(1): 25-37. 
Yukiko, Inoue (2007). Online Education for Lifelong Learning. Idea Group Inc (IGI).

Authors' address:

"Džemal Bijedić" University

Faculty of Information Technology

M. Tita bb

Bosnia and Herzegovina

e-mail: iris@edu.fit.ba

e.mail:nbijedic@edu.fit.ba

Received: November 3, 2017

Accepted for publication: January 24, 2018 